\title{
Compressed Air Energy Storage (CAES) Environmental Control Concerns and Program Plan
}

M. A. Beckwith

D. W. Boehm

June 1980

Prepared for the U.S. Department of Energy under Contract DE-AC06-76RLO 1830

Assistant Secretary for Environment

Office of Environmental Compliance and

Overview

Environmental Control Technology Division

Pacific Northwest Laboratory

Operated for the U.S. Department of Energy

by Battelle Memorial Institute 
NOTICE

This report was prepared as an account of work sponsored by the United States Government. Neither the United States nor the Department of Energy, nor any of their employees, nor any of their contractors, subcontractors, or their employees, makes any warranty, express or implied, or assumes any legal liability or responsibility for the accuracy, completeness or usefulness of any information, apparatus, product or process disclosed, or represents that its use would not infringe privately owned rights.

The views, opinions and conclusions contained in this report are those of the contractor and do not necessarily represent those of the United States Government or the United States Department of Energy.

\author{
PACIFIC NORTHWEST LABORATORY \\ operated by \\ BATTELLE \\ for the \\ UNITED STATES DEPARTMENT OF ENERCY \\ Under Contract DE-AC06-76RLO 1830
}

\author{
Printed in the United States of America \\ Available from \\ National Technical Information Service \\ United States Department of Commerce \\ 5285 Port Roval Road \\ Springfield. Virginia 22151
}

Price: Printed Copy 5

$\because$ Microfiche $\$ 3.00$

NTIS

-Pages Selling Price

$\begin{array}{ll}001-025 & \$ 4.00 \\ 026-050 & \$ 4.50 \\ 051-075 & \$ 5.25 \\ 076-100 & \$ 6.00 \\ 101-125 & \$ 6.50 \\ 126-150 & \$ 7.25 \\ 151-175 & \$ 8.00 \\ 176-200 & \$ 9.00 \\ 201-225 & \$ 9.25 \\ 226-250 & \$ 9.50 \\ 251-275 & \$ 10.75 \\ 276-300 & \$ 11.00\end{array}$


PNL-3431

33679000544934

COMPRESSED AIR ENERGY STORAGE (CAES)

ENV IRONMENTAL CONTROL CONCERNS

AND PROGRAM PLAN

M. A. Beckwith

D. W. Boehm

June 1980

Prepared for the U.S. Department of Energy under Contract DE-AC06-76RLO 1830

Assistant Secretary for Environment Office of Environmental Compliance and Overview Environmental Control Technology Division

Pacific Northwest Laboratory Richland, Washington 99352 


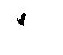

,

.

.

. 


\section{CONTENTS}

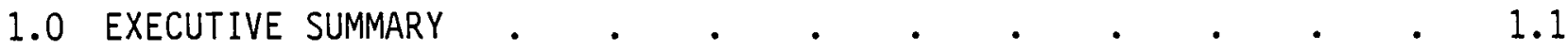

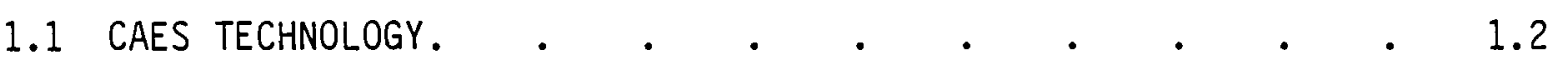

1.2 RELATED RESEARCH PROGRAMS. . . . . . . . . . 1.3

1.3 ADDITIONAL CAES.SPECIFIC RESEARCH . • . . . . . 1.3

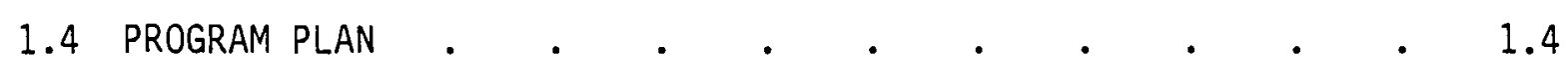

2.0 BACKGROUND INFORMATION $. \quad . \quad . \quad . \quad . \quad . \quad . \quad . \quad \cdot 2.1$

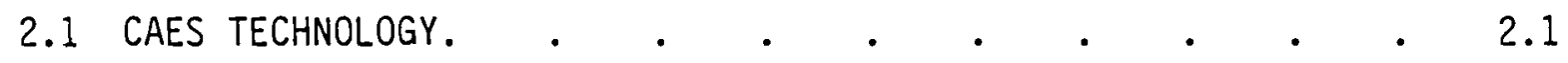

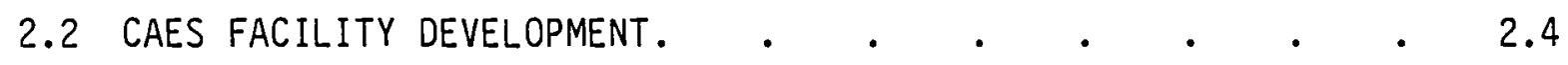

2.2.1 Current CAES Projects . . . . . . . . . 2.4

2.2.2 Potential CAES Plants and Sites . . . . . 2.5

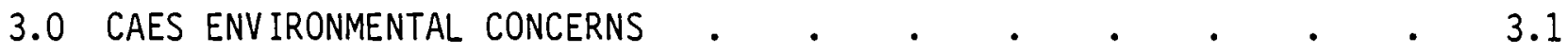

3.1 ENVIRONMENTAL IMPACTS OF CONVENTIONAL GAS TURBINE
PEAKING FACILITIES

3.2 DIFFERENTIAL IMPACTS DUE TO THE ADDITION OF CAES • $\quad . \quad \cdot 3.4$

3.2.1 Fuel Consumption . . . . . . . . . 3.4

3.2.2 Air Emissions. . . . . . . . . . . 3.5

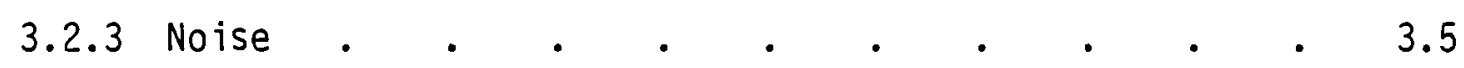

3.2.4 Aesthetic Considerations . . . . . . 3.5

3.2 .5 Greater Land Use . . . . . . . . . . 3.5

3.3 ADDITIONAL ENVIRONMENTAL CONCERNS

3.3.1 Thermal Effects at the Surface and Near-Surface . 3.6

3.3.2 Water Vapor Condensation . . . . . . . . 3.6

3.3.3 Temperature Change of the Air Storage Zone . . 3.7

3.3.4 Chemical Contamination of the Air Storage Zone--
Aquifers. . . . . . . . . 3.7 
3.3.5 Micro-Organism Contamination--Aquifers. . . 3.8

3.3.6 Thermal, Chemical and/or Micro-Organism Contamination of Bounding Aquifer Systems--Aquifers . . . . 3.8

3.3.7 Contamination of Surface Water Due to Leaching of Mine Waste Piles . . . . . . . . . 3.8

3.3.8 Contamination from Brine Reinjection . • . 3.9

3.3.9 Local Groundwater Flow Patterns--Aquifers . . . 3.9

3.3.10 Ground Subsidence from Mineral Solutioning-Aquifers, Salt . . . . . . . . 3.10

3.3.11 Ground Subsidence Due to Stress Cycling and/or Elevated Temperatures--Aquifers, Rock, Salt . $\quad 3.10$

3.3.12 Seismicity--Rock . . . . . . . . . 3.11

3.3.13 Air Leakage and Surface Blowouts--Aquifers, Rock, Salt . . . . . . . . . . . . . 3.11

3.3.14 Combustion in Reservoirs Using Depleted Hydrocarbon
Fields--Aquifers. . . . . . . . . 3.11

3.3.15 Legal/Institutional and Economic Aspects . . . 3.12

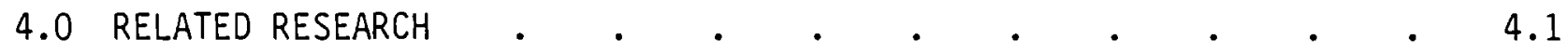

4.1 COMPLETED, ONGOING AND PLANNEd Related RESEARCH • • • • 4.1

4.1.1 Reservoir Stability Criteria Program . . . . 4.4

4.1.2 DOE-EPRI Demonstration Projects . . . . . 4.4

4.1.3 National Waste Terminal Storage Program . . . 4.4

4.1.4 Seasonal Thermal Energy Storage Program • • . 4.5

4.1.5 Geothermal Liquid Waste Disposal Program . . . 4.5

4.1.6 Huntorf CAES Plant. . . . . . . . . 4.5

4.1.7 Reinish-Westfalishes Elektrizitatswerke (RWE)
Studies. . . . . . . . . 4.6

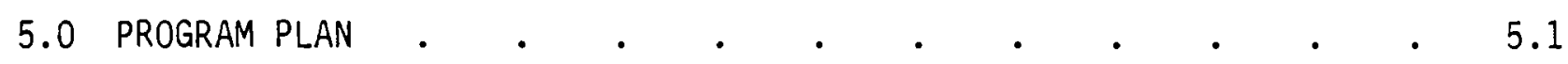

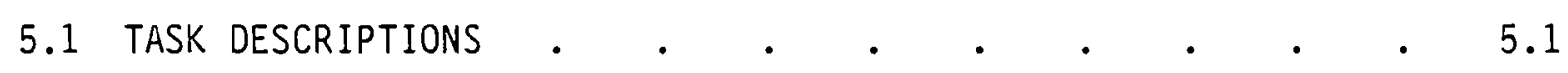


5.1.1 Task 1 - Program Management Plan . . . . . 5.1

5.1.2 Task 2 - Disposal of Mined Waste Rock Generated by
CAES Cavern Construction . . . . . . 5.1

5.1.3 Task 3 - Disposal of Brines Generated by SolutionMining CAES Caverns in Salt Formations. . . $\quad 5.2$

5.1.4 Task 4 - Limnology of Compensating Reservoirs of CAES Facilities Utilizing Such Reservoirs . . . . 5.2

5.1.5 Task 5 - Legal/Institutional Aspects of CAES Development . $. . \quad . \quad . \quad . \quad .5 .3$

5.1.6 Task 6 - Potential for Induced Geologic Phenomenon . 5.3

5.1.7 Task 7 - Review the Results of Environmental Studies Conducted for Demonstration Projects . . . . 5.4

5.1.8 Task 8 - Effects of CAES on Aquifers . . . . 5.4

5.1.9 Task 9 - Site Selection Criteria and Methodology
for CAES Facilities . . . . 5.4

5.1.10 Task 10 - Effects of CAES in Aquifers on Ground-
Water Hydrology. . . . . 5.5

5.1.11 Task 11 - Surface Effects of Plant Operation . . 5.6

5.1.12 Task 12 - Methods and Impacts of Construction of Air

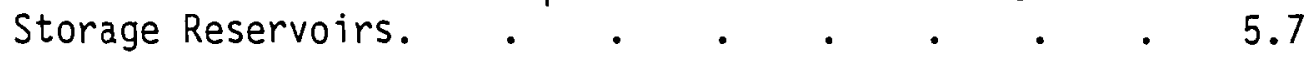

5.1.13 Task 13 - Assessment of the Economic Penalties of Control Systems/Strategies Required for CAES

Technology . . . . . . . . . 5.7

5.1.14 Task 14 - Environmental Concerns of Advanced CAES Systems. . . . . . . . . . . 5.7

5.1.15 Task 15 - Generic Environmental Assessment of CAES
Technology . . . . . . . . 5.7

5.2 RESOURCES REQUIRED TO CARRY OUT THE RESEARCH • . . . $\quad . \quad 5.8$

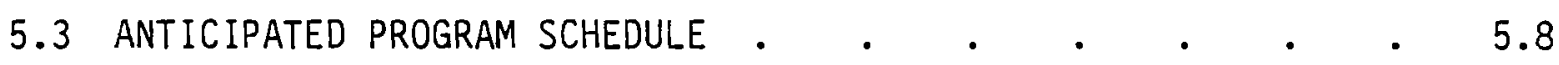

5.4 PROGRAM FUNDING SOURCES .

6.0 RECOMMENDED SPECIFIC PROGRAM RESPONSIBILITIES. . . . . . 6.1

6.1 ENVIRONMENTAL SAFETY AND ENGINEERING DIVISION. $\quad \cdot \quad \cdot \quad \cdot 6.1$ 


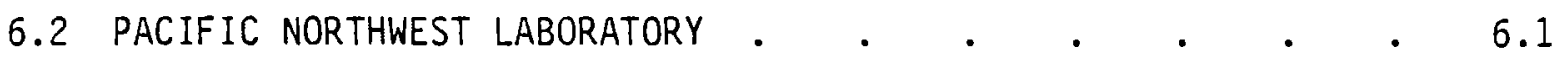

6.2.1 Proposal Review and Contractor Selection . . . 6.2

6.2.2 Technical and Administrative Management of Contracts . . . . . . . . . 6.2

6.2.3 Publication and Dissemination of Results . . . 6.3

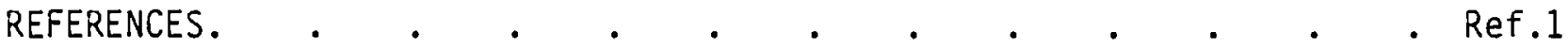




\section{FIGURES}

4.1 CAES Technology Development Program Functional

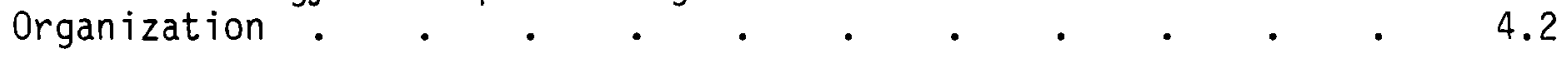

4.2 CAES Technology Development Program Work Structure Outline . . . . . . . . . . . . . . 4.3

5.1 Anticipated Task Schedule Termination . $\quad$ • $\quad$. $\quad$. 5.9

\section{$\underline{\text { TABLES }}$}

1.1 List of Research Tasks Comprising the Environmental Control Concerns Program . . . . . . . . . . . . $\quad$. 1.5

6.1 Expected Reports Resulting from the Research Tasks . . . . 6.4 


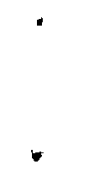




\subsection{EXECUTIVE SUMMARY}

Compressed air energy storage (CAES) is a viable technology for storing excess off-peak electrical energy from a grid in thermal-mechanical form, and recovering it later for peak-time generation of electricity. As such, its major benefit is the substantial savings in the consumption of petroleum fuels often required for peak power generation. In order to promote the early commercialization of CAES technology, it is important that significant environmental concerns be identified and adequately characterized, so that environmental control planning can be an integral part of technology development. To date, however, only limited review of the environmental impacts of implementation of CAES has been made. Potentially significant impacts have been listed and discussed in general and qualitative ways by several researchers, (1-4) but the data base required to evaluate the magnitude of specific impacts quantitatively has not been sufficiently developed.

The Pacific Northwest Laboratory (PNL) is currently the lead laboratory in the CAES technological research and development program for DOE's Thermal and Mechanical Energy Storage and Electrical Energy Systems Divisions. While many of the technological problems being addressed by this program are intimately associated with environmental concerns, minimal R\&D efforts specifically address the assessment and control of potential environmental impacts. Hence, a program to address environmental concerns directly is being sponsored by DOE'S Environmental Safety and Engineering Division (ES\&E). Furthermore, the results of these studies will provide important background data for other site-specific environmental reports.

The purpose of this report is to assess the required environmental research and to recommend a program plan to assist ECT in performing its mission of ensuring that the procedures, processes, systems, and strategies necessary to minimize any adverse environmental impacts of compressed air energy storage are developed in a timely manner so as not to delay implementation of the technology. To do so, CAES techology and the expected major environmental concerns of the technology will first be described. Second, ongoing or planned research in related programs and the applicability of results from these programs to CAES environmental research will be discussed. Third, the additional 
research and development required to provide the necessary environmental data base and resolve concerns in CAES will be outlined. Finally, a program plan to carry out this research and development effort is presented.

\subsection{CAES TECHNOLOGY}

Compressed air energy storage involves the utilization of off-peak electric power produced by large base-load generating plants to compress and store air in underground reservoirs for later recovery in the generation of peak-load power. First generation CAES facilities will use the stored compressed air for input into a modified petroleum fuel-fired combustion turbine. By supplying the turbine with air that has already been compressed, the energy content of the fuel is devoted almost entirely to generating electricity. This is in contrast to a conventional combustion turbine where up to $60 \%$ of the fuel's energy is absorbed by the compressor stage in providing the compressed air essential to operation of the combustion/expansion or power-producing stage. Only about $40 \%$ of the fuel energy content is available to do useful work such as generate electricity in a conventional combustion turbine-powered peaking plant. Therefore, by performing the compression and combustion/expansion phases (of turbine operation) at different times using a different energy source such as excess coal or nuclear-derived base-load electricity to power the compression phase, substantial savings in premium petroleum fuels can be realized in the generation of peak-load power.

Underground air storage reservoirs can be developed in three different media. Caverns can be solution mined in salt formations. Caverns can also be mined in hard rock and operated in two configurations; a constant-volume, variable-pressure cavern and a constant-pressure, variable-volume cavern connected by a water-filled leg to a surface reservoir which provides hydraulic head. Porous media such as aquifers with suitable geophysical structure and confining strata can also be used.

Environmental concerns arise primarily from construction and operation of the underground air storage reservoirs; surface impacts are similar in nature to conventional power plants. Air storage reservoir stability and integrity 
are primary environmental as well as operational concerns. Construction of reservoirs in salt and hard rock create problems of disposing of the mined wastes in an environmentally safe, aesthetically pleasing, and economical manner. Development of reservoirs in porous media such as aquifers presents the greatest potential for adverse environmental impacts, primarily because of the uncertainties involved with underground site selection. Potential impacts include alternation of local groundwater hydrology, contamination of potable aquifers, possible alternation of surface waters such as existing springs and near-surface groundwater tables, and possible adverse effects of percolation to the surface of air and/or potentially toxic gases. Hydraulically-compensated air storage reservoirs in hard rock present potential problems associated with the surface reservoir of alteration of groundwater and surface fogging and icing.

Surface impacts of CAES facilities include noise, aesthetics, atmospheric heat, water and combustion product emissions and displacement or disruption of the natural ecosystem. Such impacts are common to construction and operation of other types of generating facilities and are generally understood and accepted and for which control systems and strategies are available.

\subsection{RELATED RESEARCH PROGRAMS}

Most CAES-related research has been initiated only within the past decade. However, the natural gas industry provides a good source of underground storage experience that dates back about 50 years. Additional experience and research results will be available from other programs funded by DOE such as study of the feasibility of, and construction activities required to store nuclear waste in salt, research into geothermal energy exploitation, and study of utilizing aquifers to store heat on a seasonal basis.

Most CAES-specific research is also underway. DOE, through its Thermal and Mechanical Energy Storage and Electrical Energy Systems Divisions is sponsoring research into air storage reservoir stability and design of commercialsized CAES facilties. Work is also proceeding on developing CAES systems which require no petroleum fuel input. The Pacific Northwest Laboratory operated for DOE by Battelle Memorial Institute is the lead laboratory for these 
research efforts. In addition, DOE and the Electric Power Research Institute (EPRI) are jointly sponsoring utility demonstration projects in all three types of media considered to be utilized for CAES. An operational CAES facility near Huntorf, West Germany has been in operation since 1978 and has performed at or above its design specifications. Additional operational experience will be valuable.

\subsection{ADDITIONAL CAES-SPECIFIC RESEARCH}

Most of the technological and engineering considerations of CAES technology are being addressed in current programs. Since many environmental concerns are also engineering and operational concerns, a comprehensive analys is of environmental concerns associated with CAES will consist largely of review of the data generated in the engineering and technological development studies from an environmental perspective. The effect of existing regulations and legal doctrines on this new technology is presently unclear, as are the economic penalties and constraints imposed by them. Research of these specific issues is required.

\subsection{PROGRAM PLAN}

The CAES environmental control concerns program at PNL relies heavily on the results of the technological development and related studies. These results are analyzed and assessed from an environmental perspective. Additional research is conducted in areas where gaps exist. The program should result in a comprehensive review of all environmental conerns associated with the implementation of the technology and recommendations of the control systems and strategies required as we 11 as their economic impact, and should serve as the basis for documents prepared in compliance with the National Environmental Policy Act of 1969.

Table 1.1 provides a list of research tasks to be performed during the program. Detailed descriptions of each task is provided in Section 5.0. 
TABLE 1.1. List of Research Tasks Comprising the Environmental Control Concerns Program

Task

1

2

3

4

5

6

7
Task Description

Program Management Plan.

(Revise)

Disposal of Mined Waste Rock

(Finalize subcontractor report)

Disposal of Brines

(Finalize subcontractor report)

Limnology of Compensating Reservoirs

Legal/Institutional Aspects of CAES

Potential for Induced Geologic Phenomenon

Review DOE-EPRI Demo Project and Technological Development Studies

Effects of CAES on Aquifer Media and Groundwater Quality

Site Selection Criteria and Methodology for CAES Facilities

Effects of CAES on Ground-Water Hydrology

Surface Effects of Plant Operation

Methods and Impacts of Construction of Air Storage Reservoirs

Assessment of Economic Penalties of Control Systems and Strategies

Environmental Concerns of Advanced

CAES Concepts

Generic Environmental Assessment of CAES

Program Management 



\subsection{BACKGROUND INFORMATION}

For a more thorough understanding of the program described in this report, the following background information is provided.

\subsection{CAES TECHNOLOGY}

Compressed air energy storage (CAES) is one of several energy storage technologies currently under development. It promises to substantially reduce the amount of petroleum fuel consumed to satisfy peak load electricity demand by storing the excess output of large base-load generating stations available during periods of low demand for later recovery.

Electricity demand typically exhibits wide daily fluctuations; demand is lowest at night and highest during the day, particularly in late afternoon and early evening when much energy-consuming human activity occurs. Utilities generally rely on large generating stations that operate most efficiently at continuous output to satisfy base-load demand, that is, the minimum level of demand which remains essentially constant through time. As demand increases during the day and exceeds the base-load generation capacity, utilities relay on generating facilities whose output can be easily varied to make up the difference. As demand increases still further, for example during dinner time, exceptionally hot afternoons and cold periods, utilities bring into service peak-load generating facilities designed to provide power for short periods of time on short notice.

Base-load facililites tend to be nuclear or coal-fired because of the economics of scale offered by these fuels. However, some areas rely on oil-fired base-load generating capacity for a variety of reasons. Intermediate and peak load facilities are often coal or oil-fired, often consisting of older units near the end of their useful life held in a state of readiness until needed. By keeping the boilers continuously fired to reduce start-up time, the overall efficiency of such units is obviously reduced. Facilities designed to satisfy peak-load demand consist almost exclusively of generators driven by petroleumfueled combustion turbines or diesel engines, with the exception of conventional or pumped hydroelectric generation. 
In a CAES peak load generating plant, excess electrical power available during low demand periods would be utilized to compress and store air in underground reservoirs. Then, during peak demand periods the air would be released as input to a modified combustion turbine which drives a generator. First generation CAES facilities will require petroleum fuels. Advanced concepts envision the use of "synthetic" liquid or gaseous fuels, high pressure fluidized bed coal combustion, and some may even store and recover the heat of compression and require no additional fuel of any kind.

The primary advantages of CAES, are more efficient use of large base-load generating capacity and displacement of petroleum-fired peaking capacity. In addition to system-wide advantages, CAES peaking plants will consume substantially less petroleum fuel to generate an equivalent amount of electrical power when compared to conventional peaking turbines. The reason being that about $60 \%$ of the energy content of the fuel consumed in a conventional combustion turbine engine is absorbed in driving the compressor stage; only about $40 \%$ is available to do useful work such as drive a generator. By compressing the air necessary for turbine operation in advance using a different energy source, the energy content of the fuel consumed in a CAES plant is devoted almost entirely to driving the generator. Therefore, in comparison to a conventional combustion turbine peaking plant, an equivalent amount of electricity can be generated by a CAES plant from about $1 / 3$ the amount of fuel, or conversely, about 3 times the electricity can be generated from an equivalent amount of fuel. A comprehensive analysis must, however, include the energy source used to produce the electricity required to compress and store the air. If the power was produced by oil-fired base-load plants, no savings in petroleum would be realized, in fact, higher consumption on a system-wide basis would result because of the losses inherent in any energy storage concept. In summary, by storing energy from base-load plants in the form of compressed air, a utility could achieve more effective utilization of its most efficient and economical generating capacity while conserving premium petroleum fuels used in peak power generation. Thus, the overall utility requirements for high-cost petroleum-fueled peak generating capacity could be reduced. 
Because underground activities are involved in CAES, seasonal thermal energy storage (STES), and underground pumped hydroelectric storage, there is some overlap between these emerging technologies. Efficient utilization of resources dictates communication between these research programs. The basic technology for CAES is believed to be available now, and no significant problems are expected in incorporating this technology into existing utility networks. Furthermore, the economics appear favorable for early CAES implementation, given projected increases in petroleum fuel costs. ${ }^{(2)}$

The basic types of underground reservoirs for the storage of air in a CAES facility include:

- porous media, such as aquifers

- mined hard-rock caverns

- solution-mined caverns in salt formations

The last two types may be in "compensated" or "uncompensated" configurations. Compensated reservoirs utilize a surface water reservoir to provide hydraulic head; injected air displaces the water resulting in little pressure variation between the fully and partially charged condition. Uncompensated reservoirs, because of their constant volume, operate at variable pressure.

A significant potential problem in CAES implementation is the long-term stability of the underground reservoir. (5) A great deal of knowledge about the utilization of such reservoirs is available from decades of experience in the subsurface storage of natural gas, helium, and liquid fuels. However, the operation of a CAES reservoir is different in that the subsurface medium would be subjected to relatively rapid temperature, pressure, and humidity fluctuations as the air is injected or withdrawn in daily and weekly cycles. This is in contrast to the seasonal cycles of natural gas storage. The thermomechanical stresses to which the confining medium would be subjected during compressed air storage cycles are not satisfactorily understood and are currently being investigated. Cyclic stresses, and possibly geochemical reactions, might lead to degradation, and loss of reservoir integrity. This concern is of environmental as well as technical concern, because failure could have severe manifestations. 


\subsection{CAES FACILITY DEVELOPMENT}

This section describes both current and potential CAES projects.

\subsubsection{Current CAES Projects}

The first CAES facility to be constructed by a utility, Nordwestdeutsche Kraftwerke (NWK) of West Germany, began operating in late 1978. The 290 MW plant, near Huntorf, is designed to pump air into a solution-mined salt cavern for $8 \mathrm{hr}$ each day, using 58 MW of excess system capacity and to generate electricity for 2 hours. In actual operation, the remotely-controlled facility is started several times during the day to satisfy demand peaks.

The largest West German utility, Rheinisch-Westfalisches Elektrizitatswerk (RWE), is seriously considering a CAES system. Detailed plans have been developed for a 300-MW plant using a mined hard-rock cavern. The plant would utilize caverns operated at constant pressure using an existing pumped hydroelectric reservoir for hydraulic compensation. A final decision on the project is expected within a year.

The Department of Energy and the Electric Power Research Institute (EPRI) are currently sponsoring the development of three CAES demonstration plants. Included are an aquifer system, a salt cavity, and a hard-rock cavern. The aquifer storage demonstration program is being conducted by a consortium of utilities lead by Public Service of Indiana, the salt dome demonstration by Mid-South Services and the hard-rock demonstration by Potomac Electric Power Company. The current phase of the program is designed to specify necessary site characteristics, identify the best available demonstration sites, and complete a preliminary CAES plant design. This will be followed by a detailed plant design, equipment procurement and construction. Testing and utility operation of the demonstration plants is planned for the early 1980s. In addition to these joint industry/government sponsored projects, a few utilities have shown considerable interest in CAES. Jersey Central Power and Light, a Kansas-based consortium and a rural electric cooperative have conducted siting and system compatibility studies. 


\subsubsection{Potential CAES Plants and Sites}

Energy storage systems such as CAES are attractive in meeting future peaking capacity requirements. Conventional peaking systems utilize oil or gasfueled combustion turbines, internal combustion engines or steam plants. With increasing fuel costs, fuel shortages, and government regulations limiting the use of such fuels for electric generation, these conventional plants may become less practical as peaking options. Furthermore, studies by various investigators have identified CAES systems to be technically feasible and economically competitive as peaking power plants even under current conditions. (2) Thus, the market potential for CAES systems may be considered promising.

There is a high degree of uncertainty concerning the rate of implementation of CAES. The extent to which utilities may implement CAES plants depends on economic, institutional and technical factors, the relation of the geography of suitable storage sites to power transmission corridors and the presence of low incremental-cost base-load plants in utility systems. Analys is of regional markets and development potential indicates that geographic considerations may provide an upper limit on CAES implementation. (2) A broad review of the geology of the United States was conducted to delineate areas appearing generally suitable for underground energy storage. The general conclusion of this study is that most of the geographical United States is technically suitable for some form of compressed air energy storage. (2)

It should be noted that a driving force for implementation of underground energy storage is the presence of low incremental-cost base-load plants, such as nuclear and coal-fired plants. There exists some uncertainty concerning the rate at which utilities will introduce these large thermal plants. If the present trend to deferral or cancellation of such plants continues, the construction of CAES plants will also be retarded. Furthermore, fluctuations in fuel prices and supplies may affect the rate of CAES implementation significantly.

An important institutional consideration governing the implementation of CAES technology will be government policy towards the use of 011 and/or natural gas as a fuel for producing peak-load power. On the one hand, the use of CAES technology would result in savings of these scarce fuels. On the other hand, 
government policies restricting or prohibiting the use of these fuels may restrict the application of this technology to advanced systems currently under study using coal or other substitute fuel. 


\subsection{CAES ENVIRONMENTAL CONCERNS}

In evaluating the status and program needs of the environmental concerns of compressed air energy storage, careful site selection plays an important role in the relative magnitudes and severities of potential impacts. This is particularly true for those concerns associated with the underground components of a CAES facility. For example, the local properties of the storage rock formation will determine the likelihood of extensive air leakage, ground subsidence, or fracturing. Proper site selection would minimize most risks. other impacts such as routine construction impacts, noise, aesthetics, and atmospheric emissions are unavoidable, but are generally similar to those associated with conventional peak power generating facilities and for which control technology is available. There is some potential for catastrophic accidents, such as well blowouts, cavern collapse, induced seismicity, and aquifer contamination, but again, site selection combined with sound engineering can minimize the risks and consequences.

The assumed alternative to a CAES facility is a simple cycle gas turbine without air storage. To provide the full perspective of differential impacts of conventional gas turbine peak generating plants and CAES plants, this assessment will review the routine environmental factors of conventional gas turbine peaking facilities, the potential differential impacts and individual environmental concerns associated with CAES requiring research and development efforts.

\subsection{ENVIRONMENTAL IMPACTS OF CONVENTIONAL GAS TURB INE PEAKING FACILITIES}

The gas turbine is widely used by utilities to provide peaking power. It is a generally accepted and well-characterized technology. Facilities can be constructed and brought on-line to meet increased peak capacity needs in a relatively short time. The major disadvantage is that the turbine plant operates on premium fuels such as petroleum and natural gas. Because of the nature of peak demand, turbine plants operate at a low annual capacity factor, 
typically 5 to $15 \%$, which makes generating costs even higher. Peaking turbines are less expensive, however, than increasing the utility's base-load capacity, and are necessary because utilities must produce electricity on the demand of their customers.

The major component subsystems of a typical combustion turbine generating system are:

- the compressor train, consisting of compressors, inter- and aftercoolers, and water separators

- the expander train, consisting of regenerators, combustors and expander turbines

- the electric generator and couplings. The remainder of the plant consists of:

- a switchyard and transformer facility

- electrical and mechanical control systems

- containers (tanks) for the fuel supply.

The environmental impacts of a peaking turbine plant can be assumed known because of extensive operational experience. The most significant unavoidable impacts are (150 MW turbine):

- land use

- resource commitments -- premium fuel consumption of about 2.2 barrels of oil equivalent per MWh of electricity generated

- atmospheric emissions -- heat and combustion products

- noise.

Impacts during construction are generally those common to other types of construction projects. These include:

- displacement of local biota -- this is a site-specific impact, but displacement continues for the life of the plant

- fugitive dust emissions from land exposed during excavations or grading -- control measures are available (usually watering) to remain within air quality standards 
- emissions from hydrocarbon fuel combustion in construction machinery and in transport of workers to and from the site -- air quality standards are usually not exceeded

- runoff of water from bare ground, resulting in erosion and possible contamination of nearby surface water bodies -- the magnitude is site-dependent and control measures are available, but not entirely effective

- use of water, electricity, and raw materials in construction -- no serious depletion of these resources is encountered

- aesthetic considerations, noise from operation of construction machinery -- these are site-specific and temporary impacts

During operation of the turbine facility, the environmental impacts are:

- atmospheric emissions -- the hot combustion products are exhausted to the atmosphere but air quality standards are usually not exceeded under routine operation, particularly because of the low capacity factor (intermittent operation) and air quality regulations; heat rejection can be predicted, and is usualiy not a major impact because of the relatively small size of the plant

- noise -- operation of turbomachinery results in noise at the plant site; whether or not this constitutes a public nuisance depends on the site location, surrounding population density, and other factors.

- aesthetic considerations -- particularly the presence of high-voltage transmission lines and towers; the public has demonstrated objections to overhead lines on occasion

- potential accidents -- the major potential for accidents lies in the storage and handling of fue 1

In decommissioning a turbine facility, components would be dismantled and disposed of or recycled. The site should be restored to near the state it was in prior to construction. Similar environmental impacts can be expected during decommissioning as occur during construction. 


\subsection{DIFFERENTIAL IMPACTS DUE TO THE ADDITION OF CAES}

The differential environmental impacts between a conventional simple cycle turbine facility and a CAES turbine plant can be classified as two general types:

- the impacts having to do with the construction and operation of the aboveground : omponents of a CAES facility

- those impacts pertaining to the underground components of the CAES facility.

\subsubsection{Fuel Consumption}

In a conventional combustion turbine, the compression and combustion/ expansion stages are directly coupled. About $60 \%$ of the energy content of the fuel is devoted to driving the compressor; the remaining $40 \%$ is devoted to do useful work such as generate electricity. Separating the compression and expansion phases of turbine operation by supplying the combustion/expansion turbine with air that has already been compressed results in substantially less fuel required to generate a given amount of electricity in comparison to conventional turbine. Stated another way, a CAES turbine requires only about 4,000 BTU in premium fuel to produce 1 kilowatt-hour (KWh) of electricity while a conventional, simple cycle turbine requires about 12,000 BTU/KWh, resulting in a $60-65 \%$ reduction in petroleum fuel consumption.

Offsetting the petroleum fue 1 savings of peak generation by CAES is the increased fuel consumption at the base-load plants supplying the off-peak energy to compress the air in underground reservoirs. A comprehensive energybalance analys is of CAES must obviously include this factor. However, if the base-load plants are nuclear or coal-fired, premium petroleum fuels are conserved and large base-load plants can be operated at the high capacity factors at which they are most efficient. Therefore, use of CAES will conserve premium petroleum fuels while making more efficient use of more abundant energy sources such as coal or nuclear. Ultimately, CAES peak generating plants may require no petroleum fuel input if the advanced concepts currently under study prove feasible. 


\subsubsection{Air Emissions}

Because less fuel per unit of electricity is combusted at the site, atmospheric emissions are correspondingly lower compared to conventional gas turbine peaking plants. However, this reduction will be offset at least in part by increased emissions at the base-load plant sites. The net effect is expected to be positive, but site-specific negative impacts, as in the case of older coal-fired base-load plants may occur. Additional study is warranted as this effect will be important to full-scale commercialization of CAES technology.

\subsubsection{Noise}

The noise level of a CAES plant during the generation phase should be lower than a conventional gas turbine plant because the compressor train will not be operational. However, compressor machinery will be in operation during night-time hours and will probably require some noise abatement strategy, depending on the site.

\subsubsection{Aesthetic Considerations}

An aquifer CAES facility will require a pipe manifold system on the surface to distribute air to the wells. However, the pipes might instead be buried at a shallow depth. Compensated systems require a surface reservoir covering several acres, which will be subject to fluctuating water levels. For hard rock storage caverns, mine tailings (up to $1 \mathrm{million} \mathrm{m}^{3}$ ) may have to be piled on-site. (These impacts may also be common to underground pumped hydroelectric concepts.) These factors can constitute a degradation of aesthetic values. The impacts of additional land use, noise, and degraded aesthetics although of critical concern because of potential local opposition to CAES siting, are generally amenable to existing methods of analysis.

\subsubsection{Greater Land Use}

Considerably more land is required for the CAES facility; depending on the storage configuration, 3 to ten times as much land, or 200 to 300 acres would be required for a facility of about $1200 \mathrm{MWh}$ size. However, because more of the turbine power is available for electricity generation, the acreage per unit of electricity generated would only be 1 to 4 times greater than for the simple 
cycle facility. Several factors may prohibit the concurrent use of land overlying the storage zone such as presence of a grid of air distribution pipes (aquifer storage only and if not buried), a compensating reservoir, risk of subsidence, or on-site disposal of cavern materials. Some additional study of this issue is warranted.

\subsection{ADDITIONAL ENVIRONMENTAL CONCERNS}

Additional impacts attributed to the underground components are discussed in the following section.

\subsubsection{Thermal Effects at the Surface and Near-Surface}

In first generation CAES systems, currently under development, the temperature of the air injected into the storage reservoir will be under $100^{\circ} \mathrm{C}$ to minimize adverse effects on the storage matrix. Compressor outlet temperature will be $350^{\circ} \mathrm{C}$ or greater making the use of inter-and after-coolers necessary. A cooling system will be required to dissipate this heat. The magnitude of this concern can be predicted and the technology required to control it is readily available. Consumptive water use and discharges of heated effluent, however, may-be of concern. Advanced CAES concepts utilizing thermal energy storage (TES) to store the heat of compression for later use in the generating cycle would circumvent the concern of heat rejection to the atmosphere, but may present other concerns.

\subsubsection{Water Vapor Condensation}

When a CAES reservoir is developed in an aquifer, up to $30 \%$ of the available pore volume of the reservoir will be occupied by residual water. (6) This water will undoubtedly be evaporated by the warm, injected air, and be present in the production air stream in quantities dependent on conditions of temperature, pressure and initial humidity. It is also likely that water must be removed from the compressed air stream before injection into uncompensated hard rock and salt reservoirs, and rejected to the atmosphere. Due to the volumes of air and water vapor involved, local surface fogging and icing problems may be encountered. Another concern is that warm injected air in contact with 
water of a compensating reservoir could raise the compensating reservoir temperature sufficiently to cause fogging and icing problems in the near vicinity. In addition to surface effects resulting from operation of the subsurface facilities, the effects of water entrained in the injected compressed air on the long-term stability of the subsurface storage reservoir is of considerable concern.

\subsubsection{Temperature Change of the Air Storage Zone}

Injection of air at temperatures in excess of the local ambient would obviously heat the reservoir system. The magnitude and spatial extent of thermal effects in aquifer systems would depend on the quantity of thermal energy associated with the airstream and the apparent thermal diffusivity characteristics of the solid-air-liquid system. In the absence of interstitial liquids, the thermal energy should remain concentrated in the rock in the near vicinity of the wellbore and a steep radial temperature profile would be established. This profile would change only slowly with time via thermal conduction and gaseous diffusion. If any liquid is present, however, the apparent thermal conductivity will be significantly enhanced. Thus, temperature changes would be smaller in size near the wellbore, but greater in spatial extent. Elevated temperatures will have an impact on the physical and chemical conditions of the system and could affect reservoir stability by dehydration of the aquifer. Thermal effects would be expected to be of less significance in hard rock caverns (except the secondary effects of surface fogging in the vicinity of a compensating reservoir), and of greater significance in salt caverns where elevated temperatures affect changes in the structural properties of salt.

\subsubsection{Chemical Contamination of the Air Storage Zone--Aquifers}

Introduction of oxygen and carbon dioxide, possibly at elevated temperatures, may result in significant geochemical changes. This will only be true, however, if some degree of liquid phase water is also present. Thus once again, better definition of the temperature, pressure, and humidity conditions within the storage zone is essential. Hydrolytic and oxidation reactions and mineral solutioning and transport could result in permeability changes, 
increased corrosion potentials, and scaling. The composition and concentrations of the ground waters may be perturbed and thus, affect the waters' usability for other purposes at another time.

\subsubsection{Micro-Organism Contamination--Aquifers}

Introduction of biological organisms foreign to the air/aquifer system may be a possibility. This is especially true for the low-temperature storage concept. Identification of organism types, impact, and potential control should be undertaken. This potential impact is also applicable to the seasonal thermal energy storage concept.

\subsubsection{Thermal, Chemical and/or Micro-Organism Contamination of Bounding Aquifer Systems--Aquifers}

Under normal circumstances, the cap and bottom rocks will buffer surrounding aquifer systems from the storage zone. Since there is no significant convective mass flow through these confining strata, thermal energy can be transported only by conduction and gaseous diffusion. Therefore, thermal or chemical contamination of peripheral water systems is not considered a concern in normal operations. (Note that the maximum pressure used in charging the reservoir should be maintained below $50 \%$ of the caprock threshold pressure rating.) However, fracturing of the caprock or loss of completion cement integrity might result in creation of a convective flowpath resulting in thermal, chemical, and/or biological contamination. In addition to the impacts discussed in the previous paragraphs, mixing of fresh and saline waters is also a possibility. The potential for failure of the confining strata and borehole cement must be addressed in detail.

\subsubsection{Contamination of Surface Water Due to Leaching of Mine Waste Piles}

Contamination of surface water may occur if waste piles are leached by uncontrolled water flow. The waste pile leaching problem, hardrock or salt, is not a problem unique to the CAES concept and should be amenable to straightforward analysis. The large volume of rock produced $\left(10^{5}\right.$ to $\left.10^{6} \mathrm{~m}^{3}\right)$, however, requires that it be given early consideration. 
Waste pile leaching could be avoided entirely if the mined rock could be hauled away and sold. Therefore, a study should also be conducted to determine potential markets for crushed rock or salt. This may be crucial from an economic viewpoint as well, because the sale of rock could partially offset excavation costs. Responsibility for this area of research is currently not identified.

\subsubsection{Contamination from Brine Reinjection}

In solution mining of salt, approximately 7 to $10 \mathrm{~m}^{3}$ of brine are produced per cubic meter of salt mined. (7) Thus the salt caverns for the Huntorf facility (the only operational CAES facility) produced about 2.8 million $\mathrm{m}^{3}$ of brine.

Unless the brine can be marketed for its salt content, it must be disposed of. In compensated systems, the brine could be used during the operational phase in a surface reservoir. However, this procedure merely defers disposal until the decommissioning phase. It is likely that the brine will be reinjected since alternative disposal techniques (ponding, ocean dumping) appear to be environmentally unsound or economically prohibitive.

Considerable experience in subsurface injection of brine is available from the petroleum and underground storage industries. (6) However, the impact of injecting brine into saline aquifers above or below the air storage zone is not well documented. Both the Environmental Safety and Engineering Division and the National Terminal Waste Storage Program (nuclear) are addressing the problem in other research programs, and the generic results will be directly applicable to CAES as will the experienced gained from the DOE Strategic Petroleum Reserve Program. Once a CAES site is chosen, a site-specific assessment will be required.

Under the Safe Drinking Water Act of 1974, the Environmental Protection Agency is developing new regulations dealing with subsurface injection.(8)

The effect of the forthcoming Underground Injection Control Program as it pertains to CAES is presentiy unknown.

\subsubsection{Local Groundwater Flow Patterns--Aquifers}

Establishment of the air bubble in porous media systems may change the local groundwater flow patterns somewhat since the liquid will tend to diverge 
around the bubble and pressurizing one area of an aquifer may change the pressure regime in other areas of the same aquifer or even in other aquifers. There should be no large-scale regional change in the flow system, however. Reservoir anisotropy may complicate the issue somewhat. Site-specific groundwater computer models are clearly required. Because such models are able to best perform site-specific analyses, generic statements may be difficult or impossible.

\subsubsection{Ground Subsidence from Mineral Solutioning--Aquifers, Salt}

Thermal and/or pressure solutioning and transport of minerals like silica, calcite, and halite could lead to matrix or cavity collapse and ground surface subsidence. An ongoing program at Lawrence Berkeley Laboratories (LBL) ${ }^{(9)}$ is addressing subsidence in geothermal porous media although the added complexity of net fluid removal must be considered. Similarly, the National Waste Terminal Storage Program is studying subsidence ${ }^{(10)}$ resulting from salt solutioning and cavity collapse. The CAES program should rely heavily on these results.

\subsubsection{Ground Subsidence Due to Stress Cycling and/or Elevated Temperatures--Aquifers, Rock, Salt}

Some concern has been expressed about material fatigue due to temperature and/or pore pressure cycling. Subsequent failure of the aquifer matrix or rock cavern could induce changes in the groundwater flow and surface topography. It is anticipated that laboratory experimentation will initially address the problem followed by field verification.

Inelastic failure of a salt cavern should be similarly addressed. The rheological properties of salt are such that creep at elevated temperatures is a major concern. In addition to the temperature dependence, increased 1ithostatic pressure as a function of cavern depth may also result in accelerated closure of an artificial cavity. This problem is being addressed in other programs, especially nuclear waste storage and CAES reservoir stability criteria studies. 


\subsubsection{Seismicity--Rock}

It is clear that increasing the pore pressure in a fault zone can decrease the effective normal stress and in some cases enhance shear displacement (fault motion). This is not anticipated to be a problem in porous media or salt storage; however, it should be considered in hard rock cavern storage. If a fault were located in the immediate vicinity such that large quantities of air at elevated pressure could somehow maintain undetected communication with the fault zone, perturbation of the pore pressure might result. This appears unlikely, but from a safety standpoint it should be considered.

The converse of this phenomenon would be the relative stiffening or locking of a fault zone by decreasing the pore fluid pressure in the zone. This could transform a stable, sliding, aseismic zone into a seismically active zone.

Both of these phenomena are considered improbable with respect to CAES, but the potential impact dictates further research.

\subsubsection{Air Leakage and Surface Blowouts--Aquifers, Rock, Salt}

The natural gas and geothermal industries are well aware of the blowout phenomenon especially occurring around the casing and completion cement. This could pose a severe operational safety problem and should be explored for a CAES facility in porous media. Similar rapid loss of containment and blowdown from cavern storage is possible. Review of current technology is required. The potential for and impact of slow percolation to the surface of air and potentially toxic gases like hydrogen sulfide should also be studied.

\subsubsection{Combustion in Reservoirs Using Depleted Hydrocarbon Fields--Aquifers}

Rapid oxidation of hydrocarbons within the reservoir will occur but should have no deleterious results in of itself. What may cause problems is the venting of the oxidation products to the surface facilities and the atmosphere. In addition, the temperature of the reservoir matrix would be increased. The primary concern associated with the use of depleted hydrocarbon fields is the transport of residual hydrocarbons to the wellbore and into the surface facilities. Ignition at this point could be explosive and pose a serious safety problem and could require conditioning the reservoir to prevent this problem. 
Review of the literature relating to air injection for petroleum recovery and chemical processing should be commenced. This is a primary issue since the fate of this type of reservoir may depend on resolution of this safety problem.

\subsubsection{Legal/Institutional and Economic Aspects}

CAES is a relatively new technology, consequently the effect of existing environmental regulations and legal doctrines has yet to be determined. Interpretation by the courts and regulatory agencies will undoubtedly be required. The economic impact on the technology of compliance with such regulations also needs study. A preliminary assessment of the legal/institutional aspects of subsurface injection, storage and withdrawal of compressed air should be made to scope additional required research and prevent potential delays in deployment of this technology. 


\subsection{RELATED RESEARCH}

Most CAES research activities have been initiated only within the last decade. However, the natural gas industry provides a good source of underground storage experience that dates back about 50 years. Additional experience in this area will be available from related research programs funded by DOE. For example, the Office of Nuclear Waste Isolation (ONWI) is investigating the feasibility of nuclear waste repositories in salt formations. ONWI will be conducting, among other studies, in-situ field tests in salt cavities to investigate thermaliy-induced stresses and properties of stress at ambient temperatures. Furthermore, the Strategic Energy Reserves Program, funded by the DOE, is constructing a number of salt caverns for the storage of up to one billion barrels of crude oil. The results of their efforts to investigate the suitability of the caverns for long-term storage should be useful to the CAES program. A related program in which thermal energy is stored as sensible heat in aquifers (STES) may result in some similar concerns. In such cases, results of the CAES environmental studies may be applied to the STES program or vice versa. Finaliy, another potentially fruitful area of related research is geothermal exploitation and waste water disposal. Both the Pacific Northwest Laboratory (PNL) and the Lawrence Berkeley Laboratory (LBL) are active in these areas.

Most CAES research related to environmental concerns has been funded by DOE's Energy Storage Division (STOR). A major portion of DOE's program is directed at assessing long-lifetime suitability of underground caverns used for compressed air systems. The expected results of this segment of the program are coincident with the results sought by the Environmental Safety and Engineering Division, even though the objectives are somewhat different. Figures 4.1 and 4.2 illustrate the components of the CAES technological deve1opment program at PNL.

\subsection{COMPLETED, ONGOING AND PLANNED RELATED RESEARCH}

The following paragraphs summarize completed, ongoing and planned research directed at or related to the environmental concerns resulting from implementation of CAES plants. No specific projects within the natural gas industry 


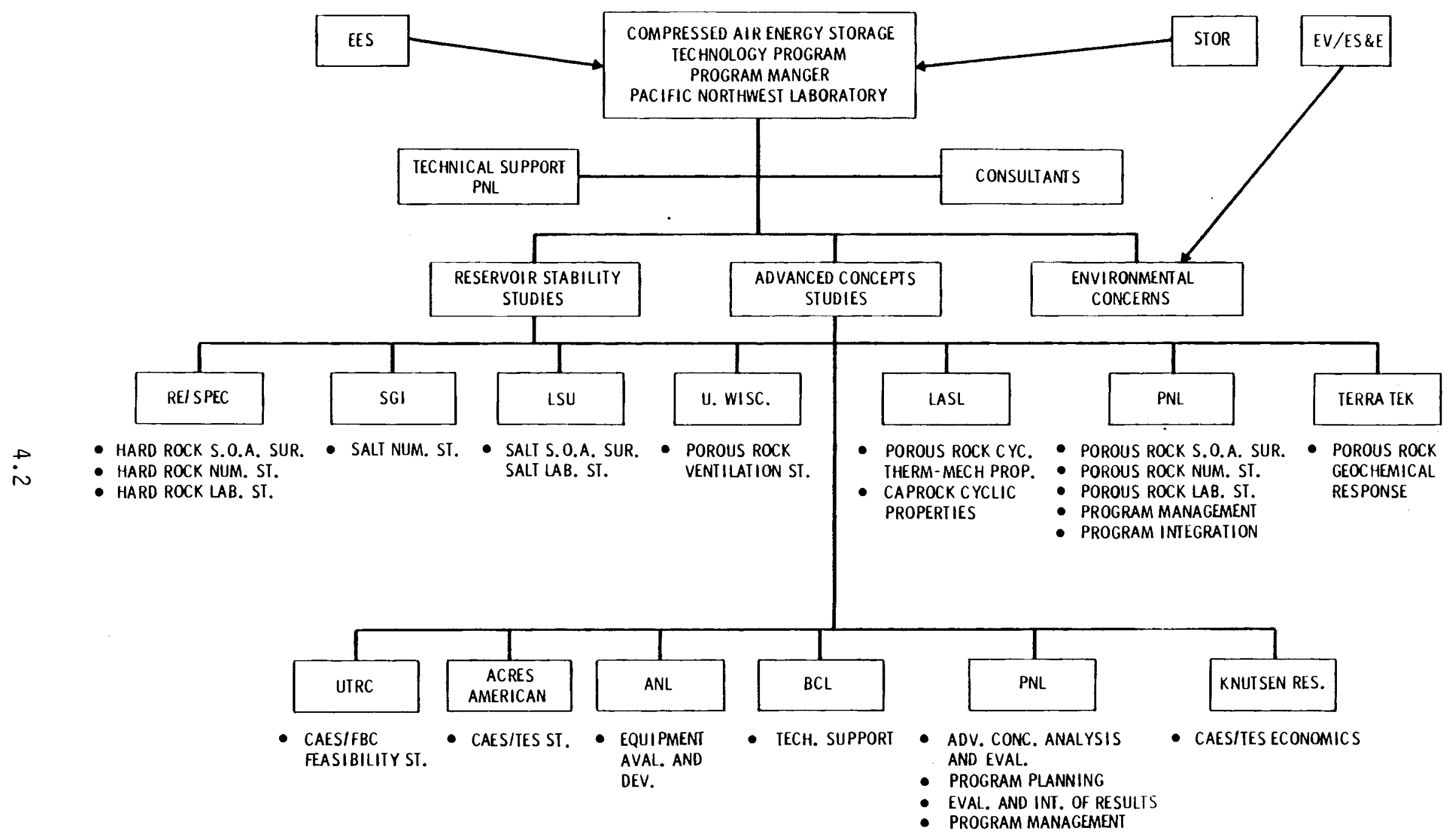

FIGURE 4.1 CAES Technology Development Program Functional Organization 


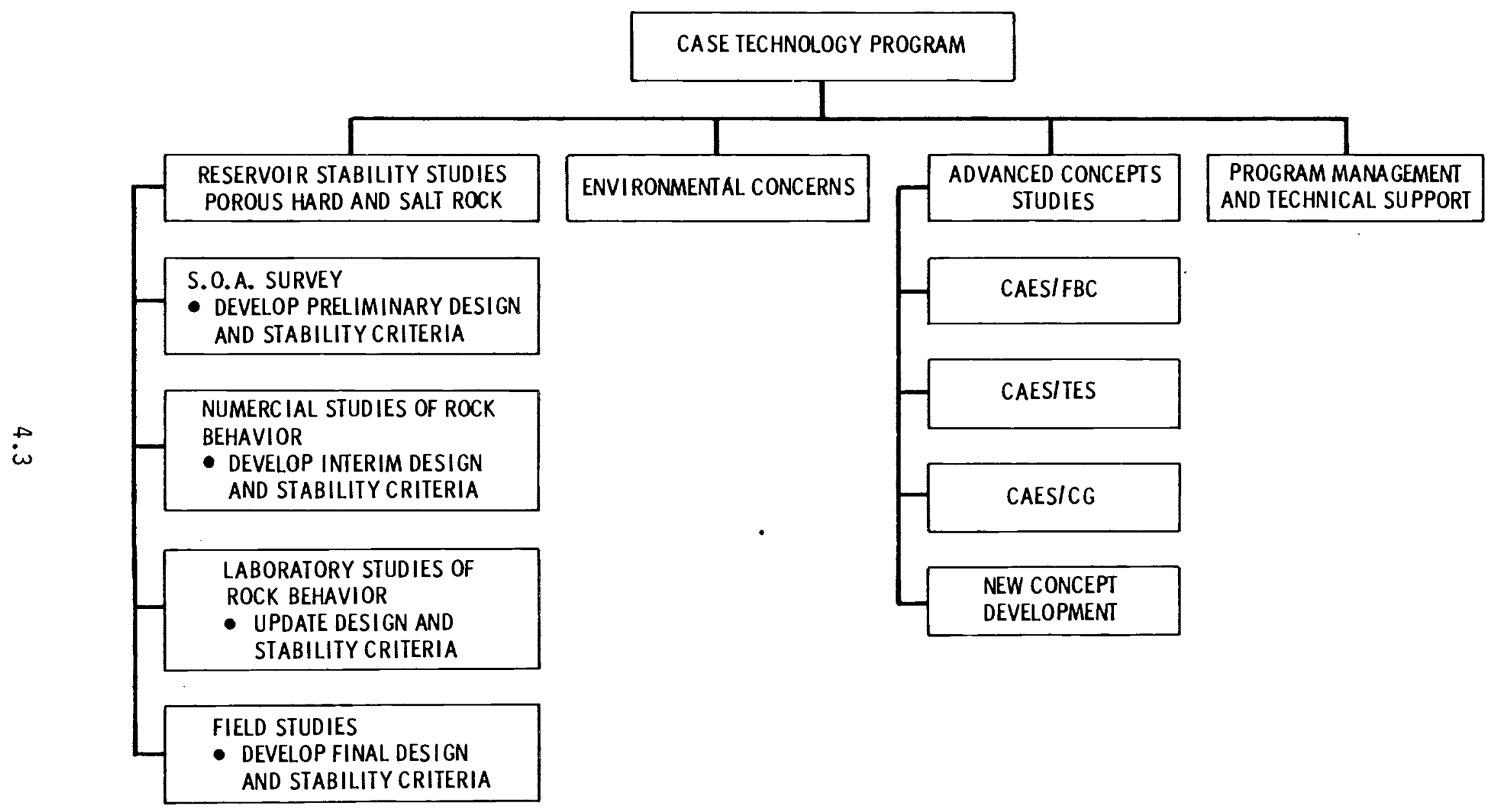

FIGURE 4.2. CAES Technology Development Program Work Structure Outline 
are cited, but its experience will be used in the research efforts on environmental issues. It should be noted that this is the first program to have been initiated with the specific objective of assessing environmental concerns of CAES.

\subsubsection{Reservoir Stability Criteria Program}

The objectives of this program, sponsored by the Thermal and Mechanical Energy Storage Division, are to determine the behavior of underground CAES reservoirs subject to pressure, temperature and humidity fluctuations. The program at PNL is divided into three subprograms according to the type of reservoir--aquifer, hardrock caverns, and solution cavity. Each subprogram is divided into four phases--literature survey, analytical modeling, laboratoryscale testing and field testing. The goal of the program is to assure utilities of the long-lifetime stability of reservoirs used for CAES in order to facilitate early CAES commercialization. However, a large number of the topics studied lend themselves readily to interpretation in terms of environmental issues.

\subsubsection{DOE-EPRI Demonstration Projects}

Three commercial-scale. demonstration projects jointly funded by DOE and the Electric Power Research Institute (EPRI) are in the planning and initial design stages. The projects will demonstrate utility feasibility of CAES in all three media planned for CAES - salt domes, hard rock, and aquifers. The utilities involved are: 1) Middle South Services plans to utilize a salt dome in Mississippi or Louisiana; 2) Potomac Electric Power Company plans a compensated CAES cavern in hard rock; and 3) Public Service of Indiana is investigating the use of an aquifer in Illinois or Indiana. Of the three, the PEPCO hard rock site is probably most advanced in the site selection, planning and design work. PSI is having difficulty finding a suitable, available aquifer formation. The experiences of these utilities should prove valuable in the commercialization of CAES technology.

\subsubsection{National Waste Terminal Storage Program}

The National Waste Terminal Storage Program was selected to site the first two nuclear waste repositories in salt formations. The Office of Nuclear Waste 
Isolation will be investigating a number of parameters that may be used in evaluating environmental issues. The program will conduct in situ field tests in salt cavities at Avery Island, Louisiana. (11) The objective is to investigate thermally-induced stresses as a function of temperature and backfill conditions, and in situ properties of stress at ambient temperatures. The program also includes extensive computer simulation and laboratory studies of the properties of salt. The results of these studies should be of significant value to ECT and the study of environmental issues.

\subsubsection{Seasonal Thermal Energy Storage Program}

This program being managed at PNL is directed at the development and demonstration of the seasonal thermal energy storage concept. In this technology, off-peak hot or cold water is pumped into an aquifer. During peak demands for heating or cooling this water is withdrawn and the sensible heat utilized. The program includes investigation of the environmental issues associated with implementation of the concept. The results of these studies may be applicable to CAES technology.

\subsubsection{Geothermal Liquid Waste Disposal Program}

This program at PNL is concerned with the management and disposal of brines produced at geothermal facilities. Brine injection studies under this program are directly applicable to CAES. Other areas that may be of value to CAES include production of noncondensible gases, subsidence prediction and control, and cross-aquifer contamination problems.

\subsubsection{Huntorf CAES Plant}

The first large-scale CAES plant for electric utility load-leveling was constructed at Huntorf, West Germany by the utility, Nordwestdeutsche Kraftwerke (NWK). The plant stores offpeak power by compressing air in underground caverns that have been leached out of a salt formation. The cavern operates at pressures between 45 and 72 atmospheres $(\mathrm{atm})$. The pressures were determined according to a set of constraints. One was associated with the difficulty of pumping out the brine after the solutioning process. Another design constraint was that the maximum pressure-time gradient should be less than $10 \mathrm{~atm} / \mathrm{hr}$. NWK chose to excavate two caverns to improve system reliability. 
Much-needed large-scale data can be obtained from the operation of this facility and applied to developing environmental controls for CAES plants in the United States.

\subsubsection{Reinish-Westfalishes Elektrizitatswerke (RWE) Studies}

RWE is considering a CAES plant for load-leveling and has developed detailed plans for a plant employing a compensated hard rock cavern. They are currently conducting reduced-scale studies on the champagne effect (in which air bubbles escape the water-filled leg because of density variations caused when cavern air is dissolved under pressure in the water). The effect, which may lead to a catastrophic blowout of the confining water leg, has been analyzed for RWE by the Institute for Hydropower at the University of Berlin. This work is being followed up by small-scale experiments. Results of these tests will be extremely important to DOE's CAES program.

Other studies have been performed that could be used for developing environmental control criteria for CAES, specifically, experience in the natural gas industry. The foregoing list, however, is considered as most pertinent to the objectives of this effort to develop a program for investigating the envirormental concerns of CAES systems. 


\subsection{PROGRAM PLAN}

\subsection{TASK DESCRIPTIONS}

The mission of the Environmental Safety and Engineering Division is to ensure that potential adverse environmental impacts associated with CAES technology are identified and that processes, systems and strategies required to minimize such adverse impacts are developed in a timely manner which avoids delays in implementing the technology. The CAES environmental control concerns program at PNL focuses primarily on the environmental-technological impacts resulting from construction and operation of underground air storage facilities. The reason for this approach is that problems of noise, atmospheric emissions, land use, water requirements, aesthetics, construction and abandonment, and other problems related to surface facilities are similar to those associated with conventional peak power plants, while the concept of cyclying air underground at elevated temperature and pressure is new and poses a number of questions that must be answered. The following is a description of tasks comprising the program which address such questions and review existing knowledge from the standpoint of application to CAES.

\subsubsection{Task 1 - Program Management Plan}

This report serves as the revised Program Management Plan. It will be revised as new information, results of the various tasks and specific requirements and requests of ECT dictate.

\subsubsection{Task 2 - Disposal of Mined Waste Rock Generated by CAES Cavern Construction}

Research into the environmental impacts of disposing of the large amounts of waste rock likely to be generated by construction of CAES reservoirs in hard rock was performed in FY-79 by subcontractors. Specific areas of concern included:

1. land requirements for disposal

2. impacts of mined wastes on natural waters

3. other uses of the mined waste rock

4. subsequent uses of the landfill

5. strategies required to mitigate potentially adverse impacts. 
A report from the subcontractor has been incorporated into a draft PNL document covering disposal of wastes generated by CAES reservoir construction.

\subsubsection{Task 3 - Disposal of Brines Generated by Solution-Mining CAES Caverns in Salt Formations}

Research into the disposal of brines generated by solution-mining CAES caverns in salt domes was also completed in FY-79 by subcontractors. Four disposal methods were assessed:

1. reinjection into saline aquifers

2. ponding

3. use of brines as industrial feedstock

4. disposal in nearby saltwater bodies

A report from the subcontractor has been incorporated into a draft PNL document concerning disposal of wastes generated by CAES reservoir construction.

\subsubsection{Task 4 - Limnology of Compensating Reservoirs of CAES Facilities Utilizing Such Reservoirs}

One configuration of CAES reservoir utilizes a surface water reservoir to maintain near-constant pressure in the air storage reservoir. As the underground reservoir is charged with compressed air, water is displaced to the surface reservoir. Conversely, as air is withdrawn from the undergound reservoir more of its volume is occupied with water. This results in wide fluctuations in the level of the surface reservoir.

Current plans call for the water reservoir to be dedicated solely to providing a hydraulic pressure-compensating head for the underground air storage reservoir. Extreme conditions of water temperature, combined with wide fluctuations in water level and the use of biocides to prevent biological fouling of equipment will likely preclude other uses of the compensating reservoir. Furthermore, the operational effects of CAES on the water of the compensating reservoir will probably preclude the use of existing water bodies.

In view of the foregoing, research performed in this task will probably be limited to four areas. 
1. Brief characterization of the water conditions likely to be found in a surface compensation reservoir.

2. Assessment of the effects of reservoir construction and operation on natural surface and groundwaters.

3. Determination of the likelihood of using existing water bodies, and probable affects of CAES facility operation on them.

4. Assessment of the effects of CAES operation on subsequent uses of the compensation reservoir after decommissioning of the facility.

\subsubsection{Task 5 - Legal/Institutional Aspects of CAES Development}

The development of CAES technology presents several new legal/institutional problems. The effects of existing legislation such as the Safe Drinking Water Act, the Fue 1 Use Act, and the forthcoming regulations by the Environmental Protection Agency concerning subsurface injection as well as legal doctrines of mineral, storage, and water rights on the development of CAES technology are presently unclear. These issues must be resolved quickly to prevent delays in implementation of the developing technology and to assess any economic penalties imposed. A comprehensive review of legal doctrines and existing and anticipated legislation as applied to CAES will be undertaken in this task.

\subsubsection{Task 6 - Potential for Induced Geologic Phenomenon}

This task will serve to condense and analyze the available information on induced seismicity and possibly subsidence. Based on this data the potential seismic enhancement due to a CAES installation on a given rock type will be evaluated. However, earthquake seismology is a very inexact science at this time. Processes that cause earthquakes are poorly understood, as are the mechanisms of rock fracture. Much additional laboratory and field data are needed before a quantitative relationship between the subsurface environment and seismic mechanisms can be established. It is probable that proper site selection will eliminate the potential for induced seismicity caused by construction and operation of CAES reservoirs, but at least a qualitative assessment is warranted. The results of this task may dictate further work. 


\subsubsection{Task 7 - Review the Results of Environmental Studies Conducted for Demonstration Projects}

The results of the environmental studies conducted in conjunction with the DOE-EPRI demonstration projects will be reviewed and assessed when they become available. Modifications in the scope of the project will be made if warranted.

\subsubsection{Task 8 - Effects of CAES on Aquifers}

Injection of air at elevated temperature and pressure into an essentially anoxic environment is bound to cause changes in the characteristics of the aquifer media and chemical composition of the groundwater. Since CAES facilities will probably not be located in potable aquifers, the effects of such facilities on adjacent aquifers of importance to the surface environment is of primary concern. This task will focus primarily on the effects of CAES on groundwater characteristics in aquifers above the air storage reservoir and in the near vicinity.

Areas of investigation will include:

1. brief characterization of the chemical and physical changes in aquifer media and water of the host aquifer

2. asessment of the possibility and effects of biological contamination

3. investigation of the likely effects on groundwater quality of air percolation through upper aquifers and eventually the soil in the event no other impermeable strata exists above the air storage reservoir.

\subsubsection{Task 9 - Site Selection Criteria and Methodology for CAES Facilities}

Most environmental problems associated with CAES technology can be minimized by careful site selection. Each underground CAES reservoir theoretically has an ideal site; one which contains all of the required geological features in the subsurface environment in combination with compatible geographical, ecological and social conditions in the surface environment. Since no completely ideal site is possible, it follows that any site chosen will 
suffer certain environmental problems that must be solved or minimized through application of specific procedures and technologies. Environmental concerns are generally a result of the site chosen and these concerns must be thoroughly understood and assessed before a final site is chosen. The correct choice of a site may be the major factor influencing the environmental issues associated with a CAES facility.

This task will assess the site selection criteria, methodologies employed and research unique to selecting sites for CAES facilities in salt formations, hard rock and aquifers. The results of the technological development studies investigating reservoir stability currently in progress at PNL and elsewhere will be utilized in the assessment.

\subsubsection{Task 10 - Effects of CAES in Aquifers on Ground-Water Hydrology}

Perhaps the greatest uncertainty and potential for adverse environmental impacts exists in storing compressed air in aquifers. Although the natural gas industry has developed the technology for storing gases underground at high pressure and amassed much operational experience, the effects on aquifer hydrology of seasonal pressure cycles as opposed to the daily pressure cycles produced by a CAES facility may be quite different.

It appears that CAES facilities will primarily utilize non-potable aquifers, for both legal and technical reasons. Therefore, the long-term effects of cycling air at elevated temperature and pressure in deep aquifers poses few environmental problems of human concern. The effects of development of an aquifer air storage reservoir on other aquifers of importance to the surface natural environment, however, is of primary concern.

Research in this task will characterize generically the effects of CAES on adjacent aquifers, and wells and surface springs in the vicinity which are used for drinking and/or irrigation water sources. In view of the sitespecific nature of hydrologic studies, generic statements about the effects of CAES on other aquifers and on surface waters may be difficult or impossible to make, in which case a "representative" site or experience may be studied instead. 
Specific areas of research will include:

1. formation of new springs and/or artesian wells

2. alteration of near-surface well production

3. changes in the physical characteristics and flow patterns of existing springs, streams and other water bodies

4. effects on the ground water hydrology in the vicinity of a CAES facility in the event of loss of integrity of the air storage reservoir

5. the monitoring system required for safe and environmentally sound operation.

\subsubsection{Task 11 - Surface Effects of Plant Operation}

In this program the alternative to CAES facilities is assumed to be conventional gas turbine peak generating plants. Gas turbine technology is a generally accepted and well characterized technology. Since first-generation CAES facilities are essentially conventional gas turbines fired by fossil fuels with the compressor and expander portions separated, the operational characteristics of noise, atmospheric emissions and resource commitements are assumed to be the same for all CAES plants regardless of the air storage system employed. Likewise, the turbomachinery required to store compressed air in the underground reservoirs is similar to all types of CAES facilities.

This task will assess the surface environmental impacts of CAES facility operation, including:

1. discharges of combustion products to the atmosphere

2. discharges of wastewater

3. consumptive water requirements

4. heat rejection to the atmosphere from cooling tower operation

5. noise

6. land requirements for the surface facilities

7. accidents. 


\subsubsection{Task 12 - Methods and Impacts of Construction of Air Storage Reservoirs}

This task will characterize and assess the construction techniques likely to be employed in construction of the various types of air storage reservoirs. Surface and subsurface environmental impacts will be assessed as will the socioeconomic impacts, labor force and capital requirements.

\subsubsection{Task 13 - Assessment of the Economic Penalties of Control Systems/Strategies Required for CAES Technology}

This task will assess the economic penalties of control systems and strategies required by CAES facilities to avoid or eliminate adverse environmental impacts.

\subsubsection{Task 14 - Environmental Concerns of Advanced CAES Systems}

Advanced CAES concepts envision the use of non-petroleum fuels such as coal. Adiabatic systems may require no fuel by storing the heat generated in the air compression stage and later recovering it to expand the stored air through the turbine to generate electricity. Such advanced systems may present environmental concerns different from the first-generation CAES systems currently under development. This task will assess those differences.

\subsubsection{Task 15 - Generic Environmental Assessment of CAES Technology}

This task will result in preparation of a generic environmental assessment following the regulations of the Council on Environmental Quality in implementing the National Environmental Protection Act. This document will be the culmination of all research and analysis performed during the program. Preparation of a formal environmental assessment will assist DOE in determining whether a formal environmental impact statement is required or will serve as the basis of a finding of no significant impact. It may be found unnecessary to prepare either of the formal documents; the topical reports resulting from the research tasks may suffice (see Table 6.1). However, some comprehensive document summarizing the results of the program will undoubtedly be prepared, especially when viewed from the standpoint of the Fuel Use Act which requires environmental documentation for granting exemptions for the use of petroleum as fuel. 


\subsection{RESOURCES REQUIRED TO CARRY OUT THE RESEARCH}

As part of a larger program designed to develop CAES technology for commercial deployment, the role of this program is to assess and analyze the results of technological development and engineering studies from an environmental perspective and to initiate research where gaps are identified. Since the development and deployment of CAES technology depends on the long-term stability and safe operation of the underground air storage reservoir, the technological development and engineering research necessarily addressed environmental concerns. Therefore, many of the tasks described in the foregoing section will primarily utilize information generated by the technological development studies currently in progress.

While much on-going research relates to the environmental concerns of CAES technology and should provide most of the desired answers, certain R\&D actions are necessary to develop the required environmental controls and procedures for underground storage of compressed air and assess the impacts on commercialization of the technology. For these reasons, tasks and elements of tasks analyzing the legal/institutional aspects of CAES and the economic penalties of necessary control and monitoring systems and strategies will also be performed.

\subsection{ANTICIPATED PROGRAM SCHEDULE}

The anticipated schedule of the program is shown in Figure 5.1. The technology development and engineering studies sponsored by DOE's Electric Energy Systems and Thermal and Mechanical Energy Storage Divisions as well as the R\&D work performed for the DOE-EPRI demonstration projects should be largely completed by the end of FY-83 or early FY-84. The CAES Environmental Control Concerns Porgram should culminate with preparation of a comprehensive environmental assessment following CEQ regulations or some other document summarizing the results of the environmental analyses and technological development and engineering studies. Such a document will aid utility as well as regulatory decision-makers in proceeding with commercial deployment of CAES technology. 


\begin{tabular}{|c|c|}
\hline Task & Task Description \\
\hline 1 & Program Management Plan \\
\hline 2 & Disposal of Mined Waste Rock \\
\hline 3 & Disposal of Brines \\
\hline 4 & $\begin{array}{l}\text { Limnology of Compensating } \\
\text { Reservoirs }\end{array}$ \\
\hline 5 & $\begin{array}{l}\text { Legal/Institutional Aspects of } \\
\text { CAES }\end{array}$ \\
\hline 6 & $\begin{array}{l}\text { Potential for Induced Geologic } \\
\text { Phenomenon }\end{array}$ \\
\hline 7 & $\begin{array}{l}\text { Review DOE-EPRI Demo Project } \\
\text { and Technological Development } \\
\text { Studies }\end{array}$ \\
\hline 8 & $\begin{array}{l}\text { Effects of CAES on Aquifer } \\
\text { Media and Water Quality }\end{array}$ \\
\hline 9 & $\begin{array}{l}\text { Site Selection Criteria and } \\
\text { Methodology for CAES Facilities }\end{array}$ \\
\hline 10 & $\begin{array}{l}\text { Effects of CAES on Groundwater } \\
\text { Hydrology }\end{array}$ \\
\hline 11 & $\begin{array}{l}\text { Surface Effects of Plant } \\
\text { Operation }\end{array}$ \\
\hline 12 & $\begin{array}{l}\text { Methods and Impacts of Con- } \\
\text { struction of Air Storage } \\
\text { Reservoirs }\end{array}$ \\
\hline 13 & $\begin{array}{l}\text { Assessment of Economic } \\
\text { Penalties of Control Systems } \\
\text { and Strategies }\end{array}$ \\
\hline 14 & $\begin{array}{l}\text { Environmental Concerns of } \\
\text { Advanced CAES Concepts }\end{array}$ \\
\hline 15 & $\begin{array}{l}\text { Gener ic Environmental Assess - } \\
\text { ment of CAES Technology }\end{array}$ \\
\hline
\end{tabular}

$\underline{F Y-79} \quad \underline{F Y-80} \quad \underline{F Y-81} \quad \underline{F-82} \quad \underline{F Y-83} \quad \underline{F Y-84} \quad \underline{F Y-85}$
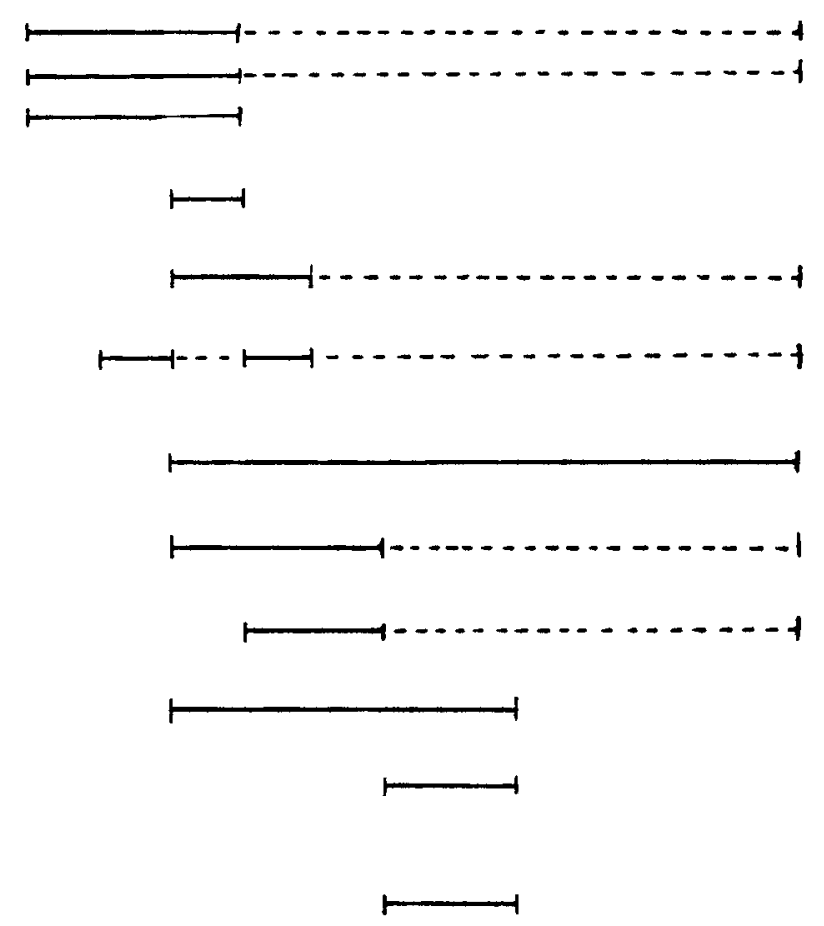

NOTE: Dashed line indicates ongoing review of the task subject following initial assessment

FIGURE 5.1. Anticipated Task Schedule

\subsection{PROGRAM FUNDING SOURCES}

As mentioned before, the CAES environmental control concerns program at PNL is funded by DOE's Environmental Safety and Engineering Division under the Assistant Secretary for Environment but relies heavily on the results of the technological development and engineering research funded by DOE's Energy Storage and Electric Energy Systems Divisions. Such an arrangement maximizes efficient use of funds by minimizing duplication of effort while at the same time ensuring that all significant environmental concerns are addressed. 


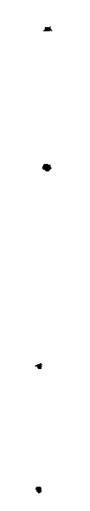




\subsection{RECOMMENDED SPECIFIC PROGRAM RESPONSIBILITES}

Specific responsibilities are recommended as follows.

\subsection{ENVIRONMENTAL SAFETY AND ENGINEERING DIVISION}

- ensure adequate and timely development of environmental control technologies for CAES

- provide selected funding support to research not readily identifiable with other DOE divisions or research required to supplement the environmental control concerns program

- maintain close liaison and communications with the PNL program manager and with other DOE divisions involved in related research

- direct and participate in preparation and periodic revision of a comprehensive Program Management Plan for the CAES environmental control concerns program

- review reports and monitor progress of all tasks

- review the program manager's progress

- approve Program Management Plan and yearly work plans

- approve reports.

\subsection{PACIFIC NORTHWEST LABORATORY}

- develop a comprehensive Program Management Plan for environmental control concerns in CAES and revise as necessary, probably on an annual basis

- prepare a yearly work plan

- maintain close liaison and communications with Environmental Safety and Engineering, Thermal and Mechanical Energy Storage Division, Electrical Energy Systems Division, and with all contractors

- prepare project scope-of-work statements and issue requests for proposals for work to be performed by external contractors 
- provide management leadership to contractors

- review reports and monitor progress of all subcontractors for conformance to scope, schedule, and cost estimates; provide reports to the DOE program monitor in accordance with contractual agreements

- anticipate problems and develop corrective actions, if necessary

- provide monthly progress reports to program monitor at ECT

- schedule program reviews

- schedule selected task reviews

- prepare annual summary report.

The technological-environmental CAES concerns program covers a wide scope of variables. It is important in this program to develop the flexibility necessary to accommodate this range of variables. PNL will provide the flexibility which the program needs and, because of its position, provide the most rapid development of the program.

\subsubsection{Proposal Review and Contractor Selection}

In its role as the lead laboratory in the Compressed Air Energy Storage Program, PNL currently seeks contractors for required research tasks and, depending upon the size of the task and expertise desired, either issues a request for proposals or seeks a sole source contract. As the coordinator for the program, the same method of operation would apply.

When proposals are solicited, a panel of experts that includes consultants from outside PNL is used to review the proposals and assist in the final contractor selection.

\subsubsection{Technical and Administrative Management of Contracts}

Under the role for PNL as the program coordinator, PNL will provide management leadership to the task contractors. It will however, be accountable to the DOE program monitor. PNL will review all reports and monitor progress of all contractors for conformance to scope, schedule, and costs. PNL will 
receive progress reports from all contractors, then submit summaries to DOE. The responsibility for scheduling all task reviews and the overall program reviews will rest with PNL.

The DOE program monitor will review all contractor selections, direct the overall program, and provide guidance on the level of effort to be expended on the overall program and its elements.

\subsubsection{Publication and Dissemination of Results}

The individual contractors on various tasks will be responsible for providing reports of their efforts. However, PNL will arrange the necessary reviews that will assure that adequate exposure is provided to all tasks. PNL will also plan periodic program reviews and schedule them with concurrence of the responsible parties at DOE.

The results of the various research tasks of the program will be clustered in such a manner as to produce internal working documents which in turn will be combined into DOE documents. Table 6.1 summarizes the reports resulting from the various research tasks and their expected draft completion dates. It must be remembered that flexibility in the program is necessary to adequately address the full range of environmental concerns in the rapidly changing environment of a large technology development program. Reports will be published as results of the research and the needs of various parties involved with CAES development dictate, with guidance and approval of the DOE program monitor. 


\section{TABLE 6.1. Expected Topical Reports Resulting from the Research Tasks}

\section{Tasks Resulting in Reports}

A) Task 1 - Program Management Plan

B) Task 2 - Disposal of Mined Waste Rock

Task 3 - Disposal of brines

C) Task 6 - Induced Geologic Phenomenon

D) Task 4 - Limnology of Compensating Reservoirs

Task 8 - Effects on Aquifer Media and Geochemistry

Task 10 - Effects on Groundwater Hydrology

Task 14 - Environmental Concerns of Advanced CAES concepts

E) Task 5 - Legal/Institutional Aspects

Task 9 - Site Selection Criteria and Me thodo logy

Task 11 - Surface Effects of CAES Plant Operation

Task 12 - Methods and Impacts of CAES Reservoir Construction

Task 13 - Assessment of Economic Penalties of Control Systems and Strategies

F) Task 15 - Environmental Assessment of CAES
PNL

Report

Description

Revised Program Management Plan

Draft

Complete

DOE

$3 / 80$

Internal working document on induced geologic phenomenon in hard rock

$9 / 80$

Internal working document

on induced geologic

phenomenon in aquifers

such as subsidence

$9 / 81$
Draft Complete

Combined report dealing

$9 / 80$

with disposal of mineral wastes; this interim report will be revised as necessary.

Final Report

Report on the surface and subsurface environmental impacts of CAES
Report on the construction and operational aspects of CAES 


\section{REFERENCES}

1. D. L. Katz, and E. R. Lady Compressed Air Storage for Electric Power Generation. Ann Arbor, MI: UTrich's Books, Inc. (1976).

2. J. B. Busch et al., Economic and Technical Feasibility Study of Compressed Air Storage. ERDA 76-76, National Technical Information Service, Springfield, VA 22151, 1976.

3. R. M. Winar, "Environmental Concerns of Underground Compressed Air Energy Storage." Proc. Workshop on Compressed Air Energy Storage Systems, Airlie House, VA, 18-19 December 1975. ERDA-76-124, pp 434-454, 1976.

4. Prel iminary Studies Concerned With an Environmental Assessment Definition for Energy Storage Systems. ATR-76 (7571)-1, The Aerospace Corporation, Germantown, MD, March 1976.

5. C. G. Smith et al., Stability and Design Criteria Studies for Compressed Air Energy Storage Reservoirs. FY-1977 Progress Report. PNL-2443, Pac if ic Northwest Laboratory, Richland, WA, March 1978.

6. A. G. Ostroff, Introduction to Oilfield Water Technology. Englewood Cliffs, N.J. Prentice-Hall, Inc.

7. Final Environmental Impact Statement, Strategic Petroleum Reserve, Seaway Group Salt Domes. DOE/EIS-0021, U.S. Dept. of Energy, Washington, D.C., June, 1978.

8. J. W. Hernandez, "Underground Injection Program Set Under Safe Drinking Water Act." Water and Sewage Works. pp. 67-69, Oct. 1977.

9. T. Simkin, "Subsidence Control Research Program". Paper presented to the DOE Environmental Control Symposium, Washington, D.C., 28-30 November, 1978.

10. Technical Support for GEIS: Radioactive Waste Isolation in Geologic Formations; Thermomechanical Stress Analys is and Development of Thermal Loading Guidelines. Office of Waste Isolation Report Y/OWI/ TM-36/20, April 1978.

11. Technical Support for GEIS: Radioactive Waste Isolation in Geologic Formations, Executive Summary. Office of Waste Isolation Report Y/OWI/TM-36/1, April 1978. 
. 


\section{DISTRIBUTION}

No. of

Copies

OFFSITE

A. A. Churm

9800 South Cass Avenue

Argonne, IL 60439

27 DOE Technical Information Center

American Public Power

Association

2600 Virginia Avenue, NW

Washington DC 20037

D. Ayers, Manager

Fluid Systems Laboratory

Westinghouse Electric

Corporation

1291 Cumber 1 and Avenue

West Lafayett, IL 47906

15

D. W. Boehm

Environmental Control Technology Branch

Environmental Safety and

Engineering Division

U.S. Department of Energy

Washington DC 20545

T. L. Brekke

University of California

Department of Civil Engineering

1847 Yosemite Road

Berkeley, CA 94707

D. E. DeViney

Commonwealth Edison Company

1319 South First Avenue

Maywood, IL 60153

Division of Advanced Energy Research and Technology

National Science Foundation

Room 1140

1800 G Street, NW

Washington DC 20550
No. of

Copies

DOE Library

U.S. Department of Energy

Mail Station $\mathrm{G043}$

Washington DC 20585

Energy Research Section

Tennessee Valley Authority

1360 Commerce Union Bank Bldg.

Chattanooga, TN 37401

A. Ferreira

Electric Power Research Institute

NEPLAN

174 Brush Hill Avenue

West Springfield, MA 01089

J. Gahimer, Chief

Thermal and Chemical Systems Branch

U.S. Department of Energy

600 E Street

Washington DC 20545

A. I. Giramonti

United Technologies Research

Center

Silver Land

East Hartford, CT 06108

Paul Gnirk

$\mathrm{Re} / \mathrm{Spec}$ Inc.

P.0. Box 725

Rapid City, SD 57701

G. E. Huck, Manager of Planning Ill ino is Power Company

500 South 27th Street

Decatur, IL 62525

2 G. D. Karadi

Thermal and Mechanical Energy Storage Division

U.S. Department of Energy

600 E Street, Room 416

Washington DC 20585 
No. of

Copies

D. L. Katz

Department of Chemical

Engineer ing

The University of Michigan

2042 E. Engr. B1dg.

Ann Arbor, MI 48109

Library

Lawrence Berkeley Laboratory

University of California

Bldg. 50, Room 134

Berkeley, CA 94720

$H$. Lorenzen

PB-KBB Inc.

Subservice Systems and Technology

800 Commerce Road West

Harahan, LA 70123

E. M. Mabuce

Manager-Applied Research Corporate Planning Dept.

Union Electric Co.

P.0. Box 149

St. Louis, MO 63166

T. J. Maiman

Sta. Mech. Engr. Dept. Manager

Commonwealth Edison Co.

36 FN West

P.0. Box 767

Chicago, IL 60690

Manager, Research and Development

Bonneville Power

Administration

P.0. Box 3621

Portland, OR 97208

T. McCafferty

Public Service Company of Indiana

1000 E. Main Street

Plainfield, IN 46168
No. of

Copies

B. J. Mueller

U.S. Department of Energy

Chicago Operations Office

9800 South Cass Avenue

Argonne, IL 60439

C. G. Nelson, Manager

Storage Operations

Northern I 11 ino is Gas Company

P.0. Box 190

Aurora, IL 60507

R. B. Newman

Soyland Power Cooperative, Inc.

P.0. Box A1606

Decatur, IL 62525

G. D. Pezdirtz, Director

Office of Advanced Conservation Technologies

U.S. Department of Energy

600 E Street, Room 416

Washington DC 20585

H. J. Pincus

University of Wisconsin

Department of Geological Sciences

Sabin Hall and Greene Museum

P.0. Box 413

Milwaukee, WI 53201

J. Rasmussen

PEPCO

1900 Pennsylvania Avenue, NW

Washington DC 20068

L. Rogers

Thermal and Mechanical Energy Storage Division

Electrical Energy Systems

Division

U.S. Department of Energy

12th \& Pennsylvania, Room 6144

Distr -5

Washington DC 20545 
No. of

Copies

Bob Schainker, Project Manager

Electric Power Research

Institute

3412 Hillview Avenue

P.0. Box 10412

Palo Alto, CA 94303

P. E. Schaub

Potomac Electric Power Company

1900 Pennsylvania Avenue

Washington DC 20006

T. Schneider

Electric Power Research Institute

Box 10412

Palo Alto, CA 94303

J. C. Smith

Division of Electrical Energy Systems

U.S. Department of Energy

12th \& Pennsylvania, Room 6144

Washington DC 20545

2 Saul Strauch, Chief

Mechanical Systems Branch

Thermal and Mechanical Energy Storage Division

U.S. Department of Energy

600 E Street, Room 416

Washington DC 20585

Stanley Stys, Vice President

American Brown Boveri

Corporation

New Brunswick, NJ 08902

J. H. Swisher, Director

Thermal and Mechanical Energy Storage Division

U.S. Department of Energy

600 E Street, Room 416

Washington DC 20585
No. of

Copies

Technical Information Department, L-3

Lawrence Livermore Laboratory

University of California

P.0. Box 808

Livermore, CA 94550

Technical Library

Department 3141

Sandia Laboratory

Albuquerque, NM 87115

W. C. Walke, Project Manager

Sargent \& Lundy Engineers

55 East Monroe Street

Chicago, IL 60603

A. H. Warnke, Vice President

Power Supply

Central Illinois Public Service Co.

607 East Adams Street

Springfield, IL 62701

D. Willett

Acres American, Inc.

Liberty Bank Building

Main at Court

Buffalo, NY 14202

L. A. Wilson

Middle South Services

P.0. Box 61000

New Orleans, LA 70161

\section{ONSITE}

3 DOE Richland Operations Office

M. White

D. K. Jones

H. E. Ransom

47 Pacific Northwest Laboratory

W. V. Loscutoff

L. D. Kannberg 
No. of

Copies

T. J. Doherty

P. L. Hendrickson

R. L. Erikson

E. Jenne

S. C. Blair

P. J. Gutknecht
No. of

Copies

L. T. Pedersen

M. A. Beckwith (20)

J. A. Stottlemyre

Technical Information Library (5) Publishing Coordination $(\mathrm{SH}) 2$

Water and Land Resources

Department Library (10) 